\title{
Frequency of Participation and Time Spent by Tribal Women of Tripura in Livestock Related Activities
}

\author{
Keshab Jamatia, M. N. Ray, S. Payeng, L. Bora, M. Johari*, N. K. Roy and D. Roy \\ College of Veterinary Science, Khanapara, (AAU) Guwahati-22, India \\ *Corresponding author
}

\begin{tabular}{|l|}
\hline Ke y w o r d s \\
$\begin{array}{l}\text { Tribal women, } \\
\text { Livestock enterprise } \\
\text { and Time spent }\end{array}$ \\
\hline Article Info \\
\hline $\begin{array}{l}\text { Accepted: } \\
18 \text { May } 2020 \\
\text { Available Online: } \\
\text { 10 June } 2020\end{array}$ \\
\hline
\end{tabular}

\section{Keywords}

Tribal women, Livestock enterprise and Time spent

Article Info

Accepted:

18 May 2020

Available June 2020

\section{A B S T R A C T}

The present study was taken up in the state of Tripura where two districts viz- Sepahijala and Gomati were purposively selected as these were mostly inhabited by Deb Barma and Jamatia tribes. Four villages from each district were selected and a total of 100 respondents were selected by Snowball sampling method making the total sample size 200. The findings revealed that majority of the respondents from Deb Barma tribe had medium level (67.00 percent) of participation in livestock farming activities followed by High (22.00 percent) and low (11.00 percent) level of participation. The mean and S.D were 38.53 and 5.589 respectively. While in Jamatia tribe a large majority of the respondents had medium (82.00 percent) level of participation followed by low (16.00 percent) level of participation and high (2.00 percent) level of participation. The mean and S.D were 40.93 and 6.212 respectively. The ' $t$ ' value was 2.871 which was significant at 0.05 level of probability. In pooled sample majority had medium level of participation (74.50) followed by low (13.50) and high (12.00) level of participation. In respect of time spent in different livestock activities, majority of the Deb Barma respondents spent medium length of time $(73.00 \%)$ followed by long time $(19.00 \%)$ and short time $(8.00 \%)$. The respondents in Jamatia tribe also exhibited similar trend with majority having spent medium length of time $(82.00 \%)$ followed by $13.00 \%$ and $5.00 \%$ in short and long period respectively. The ' $t$ ' value (3.649) was observed to be significant at 0.05 level of probability. Further, it was noticed that majority of the respondents (77.50) spent medium length of time in various livestock activities followed by those spending long period (12.00 per cent) and short period (10.50).

\section{Introduction}

Historians believe that it was women who first started growing crops and domesticating animals and thereby initiated the art and science of farming. Women have a significant and crucial position in agricultural development and allied fields. The rural women in India constitute nearly 77 percent of the total female population. About 79 percent of the rural women workers are involved in agriculture related pursuits as cultivators and labourer. Farm and home are integral parts in our society in India and the farmhouse wife acts as a producer, entrepreneur, worker, consumer and home maker. 
The female work participation rate of Tripura is 15.6 percent which is lower than all India average of 35.00 percent (NSSO, 2010). The no of unemployed women is 203 against 62 percent in the state. The occupation of the rural people in the state is agriculture and livestock sector. Among the rural people tribal people are more inclined towards rearing pigs, more especially tribal women. The tribal women actively participate in livestock management for their additional farming income but they could not earn more due to lack of proper management, remoteness, backwardness and lack of knowledge of scientific rearing of animals, lack of support and self confidence. Against this backdrop the present study was undertaken with the following two objectives include to determine the frequency of participation of tribal women in livestock related activities and also to estimate the time spent by tribal women in livestock related activities.

\section{Materials and Methods}

There are 19 recognised tribes in Tripura out of which Deb Barma, Reang, Chakma and Jamatia are considered as major tribes as per their population size. Deb Barma and Jamatia tribes were purposely selected for the study. The two districts Viz. Sepahijala and Gomati were purposely selected as the former is predominantly inhabited by Deb Barma tribals whereas the latter is predominantly inhabited by Jamatia tribes. Four villages from each district were selected and a total of 100 respondents (tribal women) were selected by Snowball sampling method. Thus a total of 200 respondents, taking 100 from each of the two tribes constitute the sample size

Time spent by respondents in livestock related activities refers to an average contribution of work in unit time (minutes) on a day in different livestock farming activities.
The respondents were asked as to how far they contribute their time(minutes) on daily routine basis in their livestock farming practices. It was measured by summing up all the average contributed time of respondents in livestock activities. An inventory was prepared to determine the frequency of participation of tribal women in livestock related activities in three point continuum and also their time spent in each to the activities on daily basis. Scoring was done by giving a score of three, two and one respectively to "Regularly" "Sometimes" and "Rarely". The inventory was pretested on 30 non sample respondents to determine its reliability and validity. Data were collected personally by the researchers from all the respondents during March and April, 2019. The collected data were processed, tabulated and frequency and percentages were calculated.

\section{Results and Discussion}

As per the result found in Table 1 it was clearly visible that majority of the respondents of Deb Barma tribe showed medium (67.00 per cent) level of participation in livestock farming which were followed by high (22.00 per cent) and low (11.00 per cent) level of participation. The mean and standard deviation obtained for this trait were 38.53 and 5.589 respectively.

While in Jamatia tribe a large majority of the respondents had medium (82.00 per cent) level of participation in livestock enterprises followed by low (16.00 per cent) and high (2.00 per cent) level of participation. The mean obtained was 40.93 and the standard deviation was 6.212.

Furthermore, in pooled data it was observed that majority of the respondents had medium level of participation in livestock enterprises (74.50 per cent) followed by low (13.50 per cent) and high (12.00 per cent) level of 
participation. The pooled mean and standard deviation were 39.73 and 6.015 respectively. The ' $t$ ' value (2.871) was observed as significant at 0.05 level of probability.

It was noticed that majority of the respondents of Deb Barma tribe spent medium level of time (73.00 per cent) followed by those spending long time (19.00 per cent) and short time (8.00 per cent) in different activities under livestock enterprises. The mean and standard deviation obtained were 108.62 minutes and 26.966 respectively.

It was interesting to notice that similar finding was obtained in Jamatia tribe where majority (82.00 per cent) of the respondents had spent medium length of time in different livestock activities followed by those spending short (13.00 per cent) and long (5.00 per cent) time. The average time spent and standard deviations were 125.255 minutes and 36.754 respectively.

Table.1 Distributions of the respondents on the basis of their participation in livestock enterprises

\begin{tabular}{|c|c|c|c|}
\hline Category & Deb Barma & Jamatia & Pooled \\
\cline { 2 - 4 } & $\begin{array}{c}\text { Frequency } \\
\text { (Percentage) }\end{array}$ & $\begin{array}{c}\text { Frequency } \\
\text { (Percentage) }\end{array}$ & $\begin{array}{c}\text { Frequency } \\
\text { (Percentage) }\end{array}$ \\
\hline Low(17-33.714) & $11(11.00)$ & $16(16.00)$ & $27(13.50)$ \\
\hline $\begin{array}{c}\text { Medium(33.714- } \\
45.745)\end{array}$ & $67(67.00)$ & $82(82.00)$ & $149(74.50)$ \\
\hline High(45.745-52) & $22(22.00)$ & $2(2.00)$ & $24(12.00)$ \\
\hline Mean & 38.53 & 40.93 & 39.73 \\
\hline Standard Deviation & 5.589 & 6.212 & 6.015 \\
\hline 't' value & & $2.871^{*}$ & \\
\hline Range & $17-49$ & $18-52$ & $17-52$ \\
\hline
\end{tabular}

Note: “*” Significant at 0.05 level of probability.

Table.2 Distributions of the respondents on the basis of time spent by them in different activities under livestock enterprises

\begin{tabular}{|c|c|c|c|}
\hline \multirow[t]{2}{*}{ Category } & Deb Barma & Jamatia & Pooled \\
\hline & $\begin{array}{c}\text { Frequency } \\
\text { (Percentage) }\end{array}$ & $\begin{array}{c}\text { Frequency } \\
\text { (Percentage) }\end{array}$ & $\begin{array}{c}\text { Frequency } \\
\text { (Percentage) }\end{array}$ \\
\hline Short $(<83.72$ mins. $)$ & $8(8.00)$ & $13(13.00)$ & $21(10.50)$ \\
\hline Medium (83.72-150.154 mins.) & $73(73.00)$ & $82(82.00)$ & $155(77.50)$ \\
\hline Long (>150.154 mins.) & $19(19.00)$ & $5(5.00)$ & $24(12.00)$ \\
\hline Mean (min.) & 108.62 & 125.255 & 116.937 \\
\hline Standard Deviation & 26.966 & 36.754 & 33.216 \\
\hline 't' value & & $3.649 *$ & \\
\hline Range (mins.) & $55-207.5$ & $52-237.5$ & $52-237.5$ \\
\hline
\end{tabular}

Note: “*” Significant at 0.05 level of probability. 
Further, it was noticed that in pooled data majority of the respondents spent medium (77.50 per cent) level of time in different activities under livestock enterprises followed by those spending long (12.00 per cent) and short (10.50 per cent) time. The pooled mean and standard deviation were 116.937 and 33.216 respectively. The ' $t$ ' value (3.649) was found to be significant at 0.05 level of probability.

\section{Participation of women in Livestock Enterprises}

It was clearly visible in Table 1 that majority of the respondents of Deb Barma tribe showed medium (67.00 per cent) level of participation in livestock farming which were followed by high (22.00 per cent) and low (11.00 per cent) level of participation. The mean obtained was 40.93 and the standard deviation was 6.21 .

Similarly, in Jamatia tribe a large majority of the respondents had medium (82.00 per cent) level of participation in livestock enterprises followed by low (16.00 per cent) and high (2.00 per cent) level of participation. The mean and standard deviation obtained for this trait were 38.53 and 5.589 respectively.

Furthermore, in pooled data it was observed that majority of the respondents had medium level of participation in livestock enterprises (74.50 per cent) followed by low (13.50 per cent) and high (12.00 per cent) level of participation. The pooled mean and standard deviation were 39.73 and 6.015 respectively. The ' $t$ ' value (2.871) was observed as significant at 0.05 level of probability.

There is no doubt that in both the tribes the farm women engaged themselves to the maximum in livestock activities but a significant difference between the two is a pointer to the higher participation of women of Jamatia tribe in livestock activities which might be attributed to their larger herd size and multiple animal and poultry related enterprises.

The result is in line with finding of Narmatha et al., (2009) who in their study found that farm women contributed in livestock farm activities in addition to their routine household duties and in which management activities were performed by them. Cent per cent actual participation was observed in feeding and watering and other activities like care of new born, care of sick animals, identification of sick animals/birds and care of animals during parturition and post parturition were performed by women.

Rathod et al., (2011) also in their study concluded that women participation was maximum in caring of pregnant animals (91.66 per cent) followed by taking animals for pregnancy diagnosis (90.83 per cent), milking (90.00 per cent), cared for new-born or young animals (89.16 per cent), cleaning of animal sheds (89.16 per cent), feeding the animals (87per cent), disposal of cow dung (86.66 per cent), farm record maintenance (52.5 per cent) and getting loans or credits from the banks (49.16 per cent).

Patel et al., (2016) also reported that women constitute about 69 per cent of workforce engaged in livestock sector.

Shafiq (2008) also revealed that most of the tasks of livestock management is performed by women ( 50 per cent and 52 per cent) as compared to men (38 per cent and 44 per cent) in Loralai and Ziarat Districts and Noushki District of Baluchistan Province of Pakistan respectively.

Ahmad, T.I. (2014) also found that 80.00 per cent work done in milk production at small farms, is by rural women in Punjab, Pakistan 
and the small farm holder women have a great role to play in realizing the potential that the country has in livestock sector.

Wahab et al., (2016) also conducted a study on 100 households in Attock District of Pakistan and found that 48per cent respondents have (20-40 per cent) sharing, 33 per cent respondents have (40-60 per cent), and the rest of 19 per cent women share (6080 per cent) with their men in livestock keeping in remote area and found that 20 per cent respondents contribute to the caring of animal, 25per cent feeding, 18 per cent watering-grazing of animal and the rest of 37 per cent respondents in cleaning of animal shading every day.

Arshad et al., (2013) also revealed that rural women were engaged in a wide range of livestock management practices such as milk processing (100 per cent), making and storage of dung cakes (90 per cent), collection of manure (87.50 per cent), caring of diseased animals (82.50 per cent), watering of animals (77.50 per cent), making feed concentrate, and feeding of livestock (75.80 per cent), cleaning of animal sheds (72.5 per cent), fodder chopping (68.30 per cent), calf rearing (67.50 per cent), marketing of animals, brooding and breeding (64.20 per cent), making animals sheds, and fodder cutting (63.30 per cent), marketing of animals, produce (60 per cent), bathing of animals (26.70per cent) and grazing of animals (0.80 per cent).

Deb Barman (2017)also found that most of the works were performed by both male and female in majority of the activity like cleaning and feeding of pig (44.50 per cent), cleaning of sty and disposal of manure (48.25 per cent), colostrum feeding of piglet (49.25 per cent), slicing and drying of tapioca (57.00per cent) and deworming and medication (49.75 per cent) found that majority of the activities performed by female were giving water to animals (53.50per cent), preparing feeds and product processing (73.75 per cent) other than sharing of activities whereas majority of men are engaged in outdoor activities like cutting and fetching fodder/ tapioca (43.25 per cent), taking to hospital or doctor (58.75 per cent), construction and repairing sty (100per cent), selling and purchasing of pig/piglets (64.75 per cent).

Bharali (2016) also in her study found that rural women participated independently in different livestock activities.

Sujeetha et al., (2017) also found that almost all the activities of dairying are performed by tribal women.

Kemprai (2009) also revealed that majority (50.55 per cent) of women had moderate level of involvement in pig rearing practices followed by high (25.00 per cent) and low (24.44 per cent) and the average involvement was 66.36 per cent which indicates moderate involvement of women in pig rearing practices.

\section{Time spent by tribal women in livestock enterprises}

Time is a precious thing for everyone in his life and therefore everybody becomes cautious in spending time in any enterprise and the proportionate profit gained from it. Women spent their valuable time in different livestock activities with the expectation of good earning from such activities.

In Table 2 it was noticed that majority of the respondents of Deb Barma tribe spent medium level of time $(73.00$ per cent $)$ followed by those spending long time (19.00 per cent) and short time (8.00 per cent) in different activities under livestock enterprises. The average time spent and standard 
deviations were 125.255 minutes and 36.754 respectively.

Similar finding was obtained in Jamatia tribe where majority (82.00 per cent) of the respondents had spent medium length time in different livestock activities followed by those spending short (13.00 per cent) and long (5.00 per cent) time. The mean and standard deviation obtained were 108.62 minutes and 26.966 respectively.

Further, it was noticed that in pooled data majority of the respondents spent medium (77.50 per cent) level of time in different activities under livestock enterprises followed by those spending long (12.00 per cent) and short (10.50 per cent) time. The pooled mean and standard deviation were 116.937 and 33.216 respectively. The ' $t$ ' value (3.649) was found to be significant at 0.05 level of probability.

The significant difference between these two tribes in terms of time spent in livestock activities is justified because the respondents from Jamatia tribe had higher participation in livestock activities than the respondents from Deb Barma tribe due to their larger herd size and multiple enterprises in livestock sector.

Similar finding was reported by Talukdar (2012) who analysed in her study that a large majority of rural women i.e. 58 per cent belonged to middle group and spent three to four hours/day in handling and managing livestock belonged to medium group followed by 32.00 per cent rural women spending two hours per day in low group and 10.00 per cent rural women in high group spending five hours and above per day. On the other hand, Borgohain and Akand (2011) mentioned that the time spending pattern of the tribal women in various animal husbandry activities in descending order, were preparing feed for animals (29.33 minutes), providing water to the animals (21.24 minutes), cleaning animal shed (20.42 minutes), grazing animals (19.28 minutes), milking (18.06 minutes), cutting and bringing fodder (16.39 minutes).

In Conclusion it can be said that in pooled data majority of the respondents had medium level of participation in livestock enterprises (74.50 per cent) followed by low ( 13.50 per cent) and high (12.00 per cent) level of participation. The pooled mean and standard deviation were 39.73 and 6.015 respectively. The ' $t$ ' value (2.871) was observed as significant at 0.05 level of probability. There is no doubt that in both the tribes the farm women engaged themselves to the maximum in livestock activities but a significant difference between the two is a pointer to the higher participation of women of Jamatia tribe in livestock activities which might be attributed to their larger herd size and multiple animal and poultry related enterprises.

Further, it was noticed that in pooled data majority of the respondents spent medium (77.50 per cent) level of time in different activities under livestock enterprises followed by those spending long (12.00 per cent) and short ( 10.50 per cent) time. The pooled mean and standard deviation were 116.937 and 33.216 respectively. The 't' value (3.649) was found to be significant at 0.05 level of probability. The significant difference between these two tribes in terms of time spent in livestock activities is justified because the respondents from Jamatia tribe had higher participation in livestock activities than the respondents from Deb Barma tribe due to their larger herd size and multiple enterprises in livestock sector.

\section{References}

Ahmad, T.I. (2014). Role of rural women in livestock management: socio economic evidences from diverse geographical locations of Punjab (Pakistan). Ph.D. 
Thesis, Geography, Université Toulouse le Mirail - Toulouse II, HAL Id: tel$00933784 \quad$ https://tel.archivesouvertes.fr/tel-00933784.

Arshad, S., Muhammad, S. and Ashraf, I. (2013). Women's participation in livestock farming activities. The Journal of Animal \& Plant Sciences, 23(1): 304-308.

Bharali, R. (2016). Economic empowerment of rural women of Assam through agrobased enterprises. Ph. D Thesis, Assam Agricultural University, Jorhat, Assam, India.

Borgohain, A. and Akand, A.H. (2011). Time utilization pattern of tribal women in animal husbandry. Indn. Res. J. Ext. Edu., 11(1).

Debbarman, C. (2017). Role of indigenous pig for sustainable livelihood security of tribal farmers in North-East India. Ph. D Thesis, C.V.Sc., Assam Agricultural University, Khanapara, Guwahati, India.

Kemprai, S. (2009). A study on role of tribal farm women in farming in Karbi Anglong district, Assam. M.Sc. Thesis, Assam Agricultural University, Jorhat, Assam, India.

Narmatha, N., Uma, V., Arun, L., and Geetha, R. (2009). Level of participation of women in livestock activities. J. Vet. Ani. Sci.5: 4-8.

Patel, S.J., Patel, M.D., Patel, J.H., Patel, A.S. and Gelani, R.N. (2016). Role of women gender in livestock sector: A review. J. Liv. Sci., 92-96.

Rathod, P.K., Nikam, T.R; Landge, S., Vajreshwari, S. and Hatey, A.(2011) Participation of rural women in dairy farming in Karnataka. Indn. Res. J. Ext. Edu.11 (2).

Shafiq, M. (2008). Analysis of the role of women in livestock production in Baluchistan, Pakistan. J. of Agri. Soc. Sci. 4(1).

Sujeetha, T.N. and Anamica, M. (2017). Role performance of Nilgiris tribal women in animal husbandry operations. International J. of Agri. Sci. and Res., 7(2): 529-532.

Talukdar, J. (2012). Status of health, empowerment and animal husbandry related to rural women. M. V. Sc. Thesis, C.V.Sc., Assam Agricultural University, Khanapara, Guwahati, India.

Wahab, P., Asharf, M.Q., Shamas-Uddin, M. A (2016). Role of women in livestock management in rural areas of district Attock, Pakistan. J. Innov. Res. and Dev.1(1):20-24.

\section{How to cite this article:}

Keshab Jamatia, M. N. Ray, S. Payeng, L. Bora, M. Johari, N. K. Roy and Roy, D. 2020. Frequency of Participation and Time Spent by Tribal Women of Tripura in Livestock Related Activities. Int.J.Curr.Microbiol.App.Sci. 9(06): 1701-1707. doi: https://doi.org/10.20546/ijcmas.2020.906.210 